\title{
HISTOLOGICAL ANALYSIS OF THE PERIAPICAL TISSUES OF DOG DECIDUOUS TEETH AFTER ROOT CANAL FILLING WITH DIFFERENT MATERIALS
}

\author{
ANÁLISE HISTOLÓGICA DOS TECIDOS PERIAPICAIS DE DENTES DECÍDUOS DE CÃES \\ APÓS OBTURAÇÃO DE CANAIS COM DIFERENTES MATERIAIS
}

Sueli Satomi MURATA ${ }^{1}$, Roberto HOLLAND², Valdir de SOUZA², Eloi DEZAN JUNIOR ${ }^{3}$, Juliana Aguiar de GROSSI ${ }^{4}$, Célio PERCINOTO ${ }^{5}$

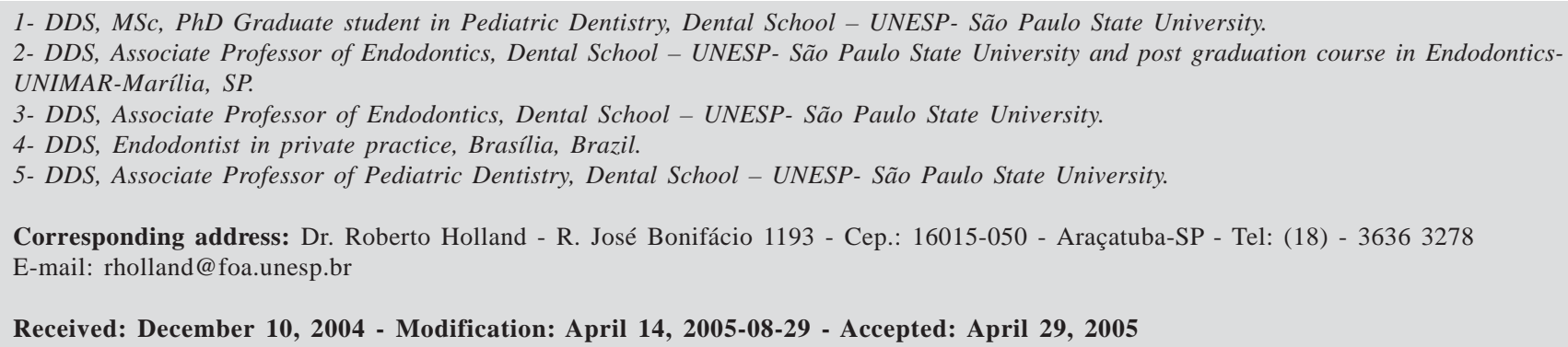

\begin{abstract}
$T$

he problem of finding an ideal material for filling root canals of deciduous teeth has not been solved yet. This fact led to the development of an experiment to histologically analyze the periapical tissue reaction to 3 root canal filling materials. Eighty root canals of dog deciduous anterior teeth from 6 animals, 60 days old, were used in this study. After biomechanical preparation, the root canals were filled with the following materials: slowly resorbable Maisto paste, Sealer 26 with iodoform, L\&C paste (calcium hydroxide with olive oil) and as a control group, canals that were prepared but not filled. At thirty days after the treatment the animals were killed and the teeth prepared for histological analysis. The materials were ranked statistically from the best to the worst as follows: a - Maisto paste, b - Sealer 26 with iodoform, c - control group, $d$ - L\&C paste. There was significant difference $(p=0.01)$ only when the results of the other groups were compared with the L\&C paste group. It was also observed that L\&C paste was not biologically compatible and that the other materials were biocompatible but their resorption was not at the same rate as that of the deciduous teeth roots.

Uniterms: Dog’s deciduous tooth; Root canal filling materials; Root canal therapy.
\end{abstract}

\section{RESUMO}

objetivo de encontrar um material ideal para obturar canais radiculares de dentes decíduos ainda não foi alcançado. Esse fato estimulou a realização de uma experimentação para analisar histologicamente a reação dos tecidos periapicais a 3 materiais obturadores de canal. Assim, oitenta canais radiculares de dentes decíduos anteriores de 6 cães, com 60 dias de idade, fora empregados neste estudo. Após o preparo biomecânico, os canais radiculares foram obturados com os seguintes materiais: pasta lentamente reabsorvível de Maisto, Sealer 26 com iodofórmio, pasta L\&C (hidróxido de cálcio com óleo de oliva) e, como grupo controle, dentes cujos canais foram preparados biomecanicamente mas não obturados. Trinta dias após o tratamento os animais foram mortos e as peças processados para análise histológica. Os resultados permitiram ordenar estatisticamente os materiais do melhor para o pior da seguinte maneira: a- Pasta de Maisto, b- Sealer 26 com iodofórmio, c- grupo controle, d- Pasta L\&C. Foi observado diferença significante $(p=0,01)$ somente quando os resultados dos diferentes grupos foram comparados com o grupo da pasta L\&C. Foi também observado que a pasta L\&C não foi biologicamente compatível enquanto os outros materiais foram biocompatíveis, porém suas velocidades de reabsorção não foram a mesma observada com as raízes dos dentes decíduos.

Unitermos: Dentes decíduos de cães; Materiais obturadores do canal radicular; Tratamento de canal. 


\section{INTRODUCTION}

According to Castagnola and Orlay² (1956) the material for filling root canals of deciduous teeth must be resorbed simultaneously with the roots and not be harmful to the permanent tooth bud. It must also be radiopaque, antiseptic, easily removed if necessary, not alter the tooth color, as well as have other properties. Numerous experiments have studied various root canal filling materials ${ }^{1,4,5,12,17,21}$, but the ideal filling material has still not been found.

The filling materials available may be slowly resorbed, quickly resorbed, and some that are almost not resorbed at all ${ }^{9,10,17,19}$. It is possible that the ideal material for deciduous teeth is among the slowly resorbed filling materials. Examples of slowly resorbed filling materials are calcium hydroxide pastes with oil vehicles and Maisto paste ${ }^{15}$. Maisto and Erausquin ${ }^{16}$ (1965) observed biological closure and resorption of Maisto paste after root canal filling of rat teeth. The same was observed in dog teeth ${ }^{7}$. Lopes and Costa Filho ${ }^{14}$ (1988)employed a calcium hydroxide paste with olive oil as the vehicle (L\&C paste) in root canal filling of human permanent teeth with periapical lesions. They observed healing with little resorption of the paste in the canal. Alves, et al. ${ }^{1}$ (1994) and Péret ${ }^{18}$ (1999) filled root canals of human deciduous teeth with L\&C paste. They reported clinical and radiographic healing processes in almost all cases.

Biological closure by newly formed cementum was observed after root canal filling of dog teeth with Sealer 26, a calcium hydroxide root canal filling material ${ }^{19}$. When implanted in subcutaneous connective tissue of rats there was deposition of calcite crystals and a bridge of Von Kossa positive material ${ }^{11}$. Nevertheless, this material must be better analyzed because of contradictory results observed in the literature ${ }^{13}$

Kubota, et al. ${ }^{12}$ (1992) and Holan and Fuks ${ }^{5}$ (1993) reported that despite the great number of papers that studied root canal filling materials for deciduous teeth, the ideal filling material is not known. Sealer 26, L\&C paste and Maisto paste have not been studied histologically in deciduous teeth. Thus, the object of this paper is to histologically analyze the results after root canal filling of deciduous dog teeth with Sealer 26, L\&C paste or Maisto paste.

\section{MATERIALS AND METHODS}

This study was approved by the Bioethics Committee of UNESP- São Paulo State University.

Eighty root canals of deciduous anterior teeth of 6 mongrel dogs of the same litter and 60 days old were used in this study. Intravenous sodium pentobarbital was used for general anesthesia. The pulp chamber of each tooth was opened after rubber dam placement. The pulp was removed with barbed broaches and Hedstrom files. Radiographs were taken to control the level of instrumentation at $1.0 \mathrm{~mm}$ short of the apex. All incisors were instrumented with Kerr files from \# 10 up to 30 and the canines from \# 30 up to 45 . The canals were thoroughly irrigated with saline during and after biomechanical preparation.

After final irrigation, the canals were carefully dried with paper points and filled with the studied materials. The pastes and the sealer were delivered to the canal with a lentulo spiral drill. The filling level was corrected with Kerr files after a radiographic control. The coronal access of all teeth was filled with IRM and amalgam. This resulted in 4 groups of 20 root canals each treated as follows:

Group I - root canals filled with Maisto paste (Inodon Porto Alegre - Brazil). This paste has the following composition: zinc oxide (14g), iodoform (42g), thymol (2g), camphorated chlorophenol (3mL) and anhydrous lanoline (0.5g).

Group II - root canals filled with L\&C paste (Herpo Petrópolis - Brazil). This paste has the following composition: liquid - olive oil; powder - calcium hydroxide (2g), bismuth carbonate (1g), rosin (0.05g).

Group III - root canals filled with Sealer 26 (Dentsply Petrópolis - Brazil). This sealer has the following composition: powder - calcium hydroxide (37\%), urotropine (15\%), bismuth trioxide (43\%), titanium dioxide (5\%); liquid - epoxy bisphenol resin (100\%). The paste was prepared mixing the powder with iodoform (Probem - Catanduva Brazil) in equal parts, in order to render the sealer resorbable ${ }^{18}$.

Group IV - Control. The canals were prepared in the same way as the other groups, then left empty. The coronal access was filled with IRM and amalgam.

Thirty days after the treatment, the animals were killed by administration of an overdose of general anesthetic. The specimens were fixed in $10 \%$ neutral-buffered formalin solution and decalcified in formic acid-sodium citrate. Segments of the jaws, each containing one tooth, were prepared for histological examination. The specimens were embedded in paraffin, serially sectioned to an average thickness of $6 \mu \mathrm{m}$, and stained with hematoxylin and eosin (H\&E) and the Brown and Brenn technique.

The histological specimens were evaluated by one of the authors, according to the following criteria: newly formed cementum, lateral and apical root resorption, bone tissue resorption, inflammatory reaction (chronic or acute, number of cells and extension of the reaction), periodontal ligament (thickness and organization), root canal filling limit, presence of debris, presence of microorganisms, filling material resorption (Table 1). These histological parameters were scored for each specimen on a scale of 1 to 4,1 being the best result and 4 the worst. The scores of the 20 specimens of each group were analyzed using the KruskalWallis statistical test.

\section{RESULTS}

\section{Maisto paste}

The filling material was $1.0 \mathrm{~mm}$ short of the apex in 11 cases. In 9 cases there was overfilling. Variable amounts of debris were observed in 18 cases. Resorption of the apical 
portion of the roots was observed in all cases (Figure1). The dimensions of the resorbed areas were variable, sometimes exposing the filling material. In some cases there was ingrowth of periodontal connective tissue suggesting resorption of the filling material. In these cases there was also dentin resorption and deposition of newly formed cementum in the root canal walls.

The apical resorptions put the filling material in contact with periapical tissues that exhibited chronic inflammatory reactions of varying intensity and extension, with giant cells and macrophages (Figure 2). A mild neutrophilic infiltrate was also observed in 6 cases. The periodontal ligament exhibited a mean thickness of $342 \mu \mathrm{m}$ and was well organized in one case, while in the other specimens it was disorganized or partially organized.

The coronal and middle thirds of the root did not exhibit resorption areas in 9 cases. There were areas of resorption in the remaining cases, generally more pronounced on the lingual surfaces. In 17 cases there was newly formed cementum partially repairing some resorption areas.

The Brown and Brenn technique showed Gram-positive microorganisms in only 1 case, in the central part of debris located in the more apical part of the root.

\section{L\&C paste}

In 3 cases the filling material was confined to the canal. In the remaining cases there was overfilling. Debris was observed in 17 cases, generally in a small amount. All specimens exhibited apical resorption areas, generally active and exposing the filling material (Figure 3).

The filling material in contact with the apical connective tissue elicited a severe inflammatory reaction with lymphocytes, macrophages and plasma cells in all cases, as well as neutrophils in 13 specimens (Figure 4). In few cases there was ingrowth of periodontal connective tissue suggesting resorption of the filling material. This connective tissue exhibited a chronic inflammatory reaction and also neutrophilic infiltrate. Next to the filling material there were macrophages and giant cells with particles of the filling material in their cytoplasm.

Apical deposition of newly formed cementum was observed in 5 cases. There was complete apical closure in 2 specimens, partial closure in 2 other cases and only deposition of cementum in the apical walls in 1 specimen. The periodontal ligament exhibited an average thickness of $522 \mu \mathrm{m}$. It was totally disorganized in 11 cases and partially organized in the remaining specimens.

In 13 cases there were resorption areas in the coronal and middle thirds of the root, more evident on the lingual surfaces.

The Brown and Brenn technique showed Gram-positive microorganisms in 7 specimens. These microorganisms were more frequently observed in the apical third of the roots, in the dentin walls and debris. In 2 cases microorganisms were observed in the dental pulp residue adhering to the dentin

TABLE 1- Mean scores of the different histomorphological events for the experimental and control groups

\begin{tabular}{|c|c|c|c|c|}
\hline \multirow[t]{2}{*}{ HISTOMORPHOLOGICAL EVENTS } & \multicolumn{4}{|c|}{ GROUPS } \\
\hline & Maisto & L\&C & Sealer 26 & Control \\
\hline Ligament thickness & 2.35 & 3.35 & 2.35 & 2.45 \\
\hline Ligament organization & 2.90 & 3.45 & 2.80 & 2.25 \\
\hline Acute inflammatory infiltrate intensity & 1.40 & 2.95 & 1.20 & 1.60 \\
\hline Acute inflammatory infiltrate extension & 1.55 & 2.75 & 1.20 & 1.60 \\
\hline Chronic inflammatory infiltrate intensity & 2.60 & 3.90 & 2.20 & 1.95 \\
\hline Chronic inflammatory infiltrate extension & 2.65 & 3.70 & 2.35 & 2.00 \\
\hline Filling level & 1.95 & 3.20 & 1.85 & - \\
\hline Filling material resorption & 2.20 & 1.85 & 2.40 & - \\
\hline Debris & 2.70 & 1.95 & 2.10 & 1.20 \\
\hline Apical resorption extension & 2.95 & 3.60 & 3.00 & 3.65 \\
\hline Apical resorption depth & 3.25 & 3.80 & 3.70 & 3.95 \\
\hline Buccal lateral resorption extension & 1.65 & 1.50 & 1.90 & 2.10 \\
\hline Buccal lateral resorption depth & 1.60 & 1.55 & 1.95 & 2.05 \\
\hline Lingual lateral resorption extension & 1.85 & 1.90 & 2.60 & 2.45 \\
\hline Lingual lateral resorption depth & 1.95 & 2.05 & 2.50 & 2.50 \\
\hline Bone tissue resorption & 2.30 & 2.60 & 2.40 & 2.30 \\
\hline Lateral cementum deposition & 2.20 & 2.50 & 2.85 & 3.05 \\
\hline Apical cementum deposition & 3.55 & 3.45 & 3.35 & 3.55 \\
\hline Microorganisms & 1.15 & 2.05 & 1.00 & 1.60 \\
\hline General mean* & $2.25 a$ & $2.74 b$ & $2.30 a$ & $2.36 a$ \\
\hline
\end{tabular}

* Means followed by the same letters do not differ statistically. There was a significant difference $(p=0.01)$ among the different letters. 
wall and in contact with the filling material (Figure 5).

\section{Sealer 26}

In this experimental group there were only 3 cases of overfilling. Debris was observed in 15 specimens in variable amounts.

The apical third of the root exhibited resorption areas usually exposing the filling material to the periodontal connective tissue (Figure 6). Tissue in contact with the filling material had varying amounts of chronic inflammatory infiltrate. Next to the filling materials there were macrophages and giant cells with filling particles in their cytoplasm (Figure 7).

Newly formed cementum produced complete biological closure of the apical foramen in 1 case and partial closure in 5 others. The periodontal ligament exhibited a mean thickness of $298 \mu \mathrm{m}$ and was well organized in 2 cases, partially organized in 13 specimens and disorganized in 5. The periodontal ligament exhibited a chronic inflammatory reaction whose intensity and extension varied from mild to severe.

The middle and coronal thirds of the root exhibited

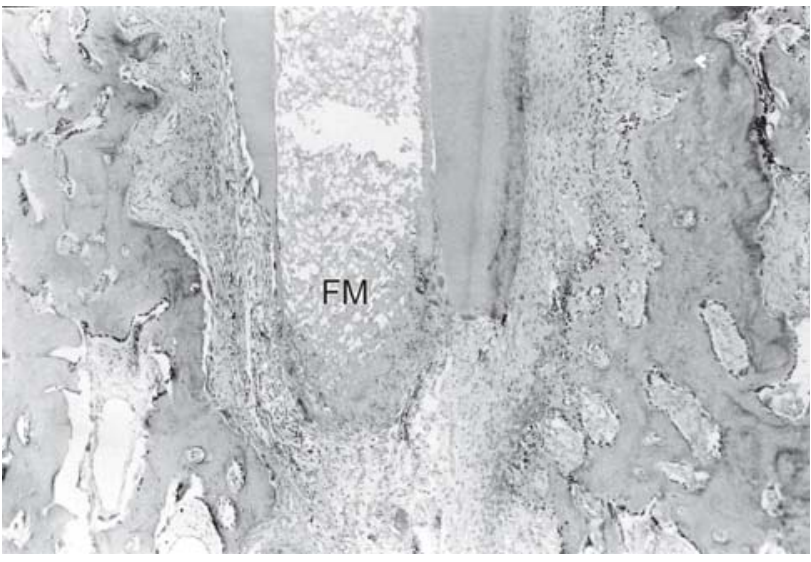

FIGURE 1- Maisto paste. There is more resorption of the apical third of the root than of the filling material (FM). H.E. X 40

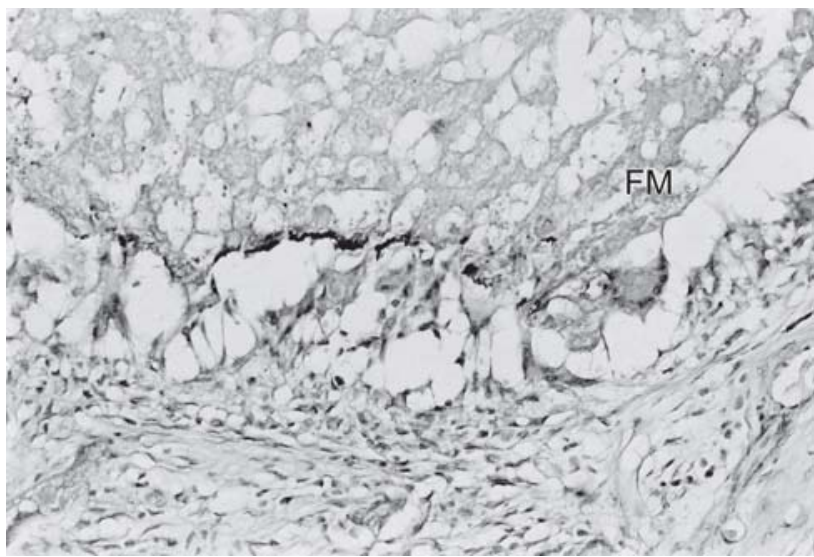

FIGURE 2- Maisto paste. The filling material (FM) is surrounded by giant cells and some chronic inflammatory cells. H.E. X. 200 resorption areas of different extension and depth, at times exposing filling material within the canal. Generally these resorption areas were more evident on the lingual surfaces. The exposed filling material elicited a chronic inflammatory reaction. The chronic inflammatory reactions in the apical and lateral portions of the roots exhibited macrophages and giant cells with particles of the filling material in their cytoplasm.

The Brown and Brenn technique did not exhibit microorganisms in the twenty cases examined.

\section{Control group}

There was apical root resorption in all specimens, exposing the interior of the root canal to the periodontal connective tissue. There was ingrowth of connective tissue that reached the coronal seal of IRM. At this point there was a basophilic layer and a mild chronic inflammatory reaction.

In 9 cases there was invagination of connective tissue and newly formed cementum in the root canal walls (Figure 8). The periodontal ligament exhibited a mean thickness of $307 \mu \mathrm{m}$ and was well organized in 7 cases, partially organized

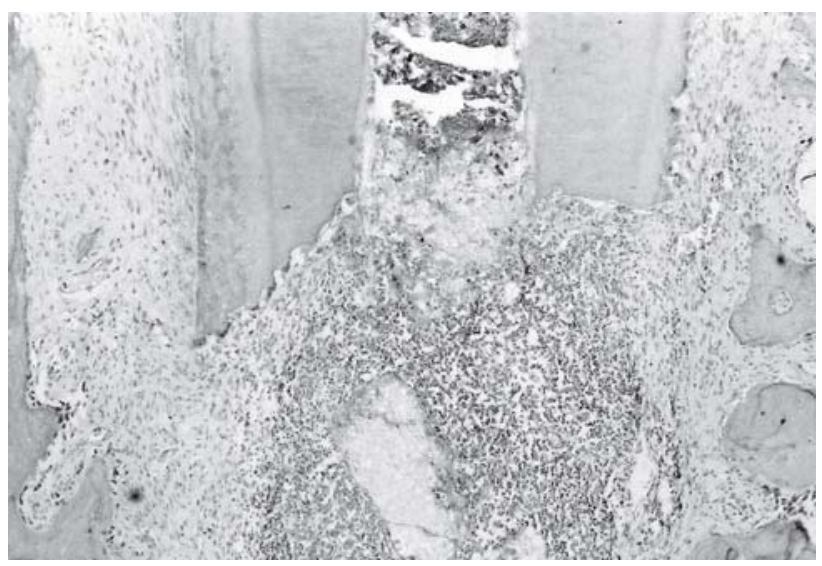

FIGURE 3- L\&C paste. Observe resorption of the apical third of the root and presence of intense inflammatory reaction. H.E.X 40

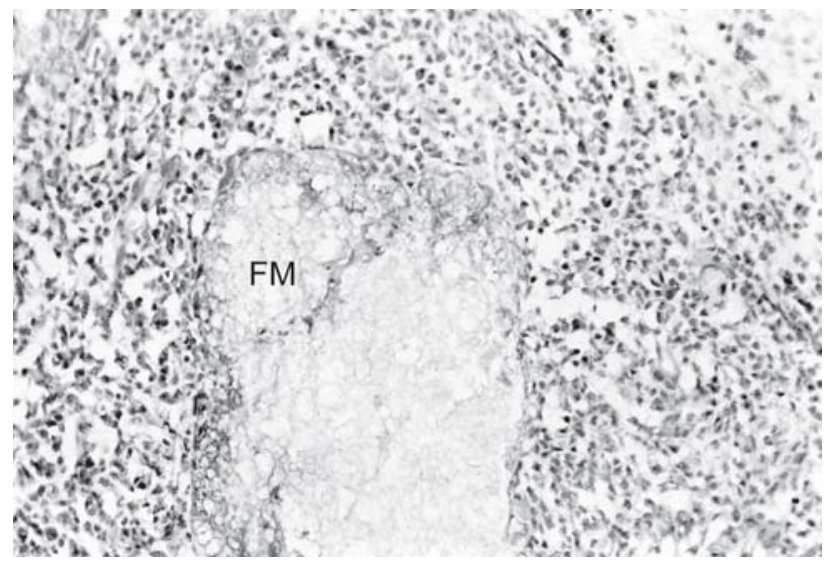

FIGURE 4- Higher magnification of Figure 3. Neutrophils and chronic inflammatory cells are surrounding a particle of the filling material (FM). H.E. X 200 
in 7 and disorganized in the remaining cases.

Lateral root resorptions were observed in the middle and coronal thirds. These resorptions were more evident on the lingual surfaces and exhibited different depths and extensions.

The Brown and Brenn technique showed Gram-positive microorganisms in 4 specimens on debris localized next to the canal walls in the apical third of the roots.

The general mean of the scores of the histomorphological data of all the groups is presented in Table 1.

\section{Statistical analysis}

The scores attributed to all specimens were analyzed by the Kruskall-Wallis statistical test. This test ranked treatment from best to worst as follows: Maisto paste, Sealer 26 cement, control group, L\&C paste. A significant difference $(P=0.01)$ was observed only when the results of the other groups were compared with that of the L\&C paste.

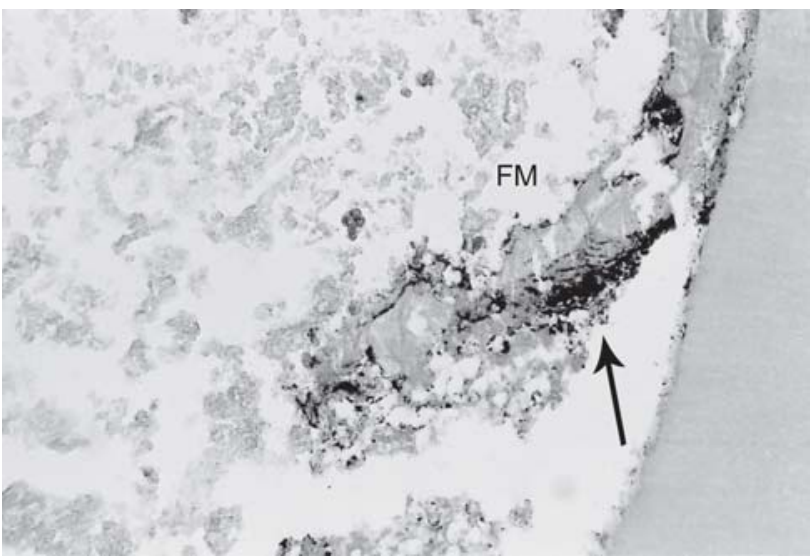

FIGURE 5- L\&C paste. There are Gram-positive microorganisms (arrow) in debris next to the filling material (FM). Brown and Brenn. X 200

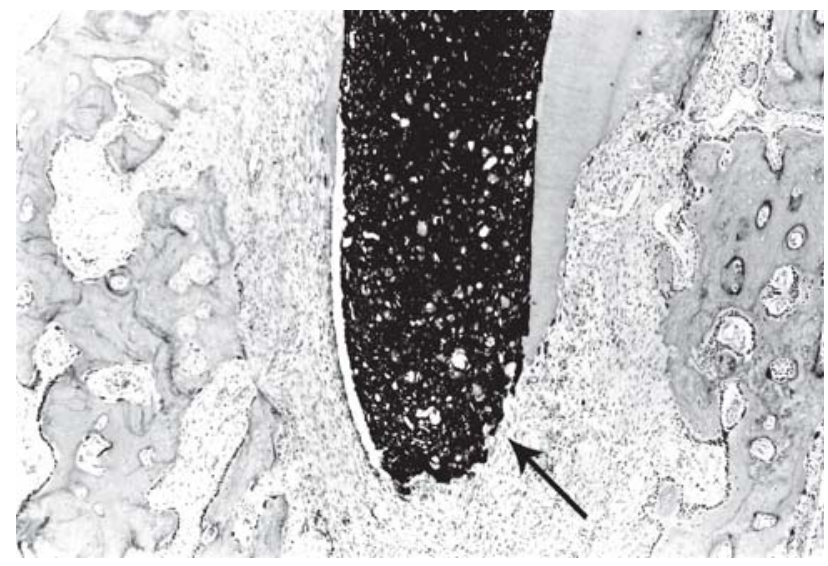

FIGURE 6- Sealer 26. Note great resorption of the apical third of the root and only little resorption of the filling material (arrow). H.E. X 40

\section{DISCUSSION}

In our experiment the results obtained with the L\&C paste were not good, mainly because of the severity of the chronic and acute inflammatory reactions observed in almost all cases. Our results, as well as that of Silva, et al. ${ }^{20}$ (1991), did not support the clinical results reported by Lopes and Costa Filho $^{14}$ (1988) in human permanent teeth and by Alves, et al. ${ }^{1}$ (1994) and Péret $^{18}$ (1999) in human deciduous teeth. It is possible that the observed results have some relation to the carrier vehicle employed (olive oil) because with other non water soluble vehicles the reported results with calcium hydroxide were better. Good histological results were reported in dog permanent teeth with calcium hydroxide camphorated p-monochlorophenol or silicone oil ${ }^{8,10}$. The same results were observed in dog deciduous teeth with camphorated p-monochlorophenol ${ }^{2}$ as the vehicle. Another interesting fact with the L\&C paste was the presence of microorganisms in debris practically in contact with the paste, suggesting absence of bactericidal action. It is possible that olive oil hinders the bactericidal action of calcium hydroxide, which did not occur with other oil based vehicles $^{3,6}$.

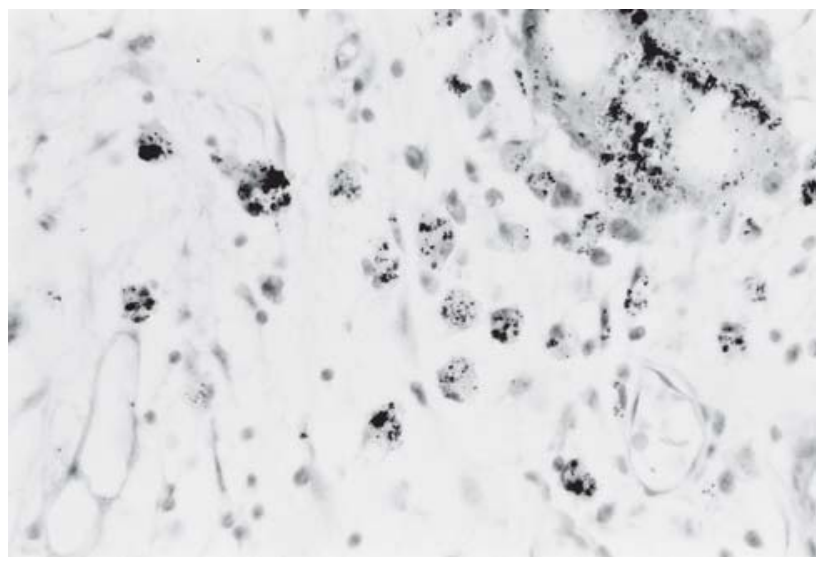

FIGURE 7- Sealer 26. There are macrophages and giant cell with particles of the filling material in their cytoplasm. H.E. X 200

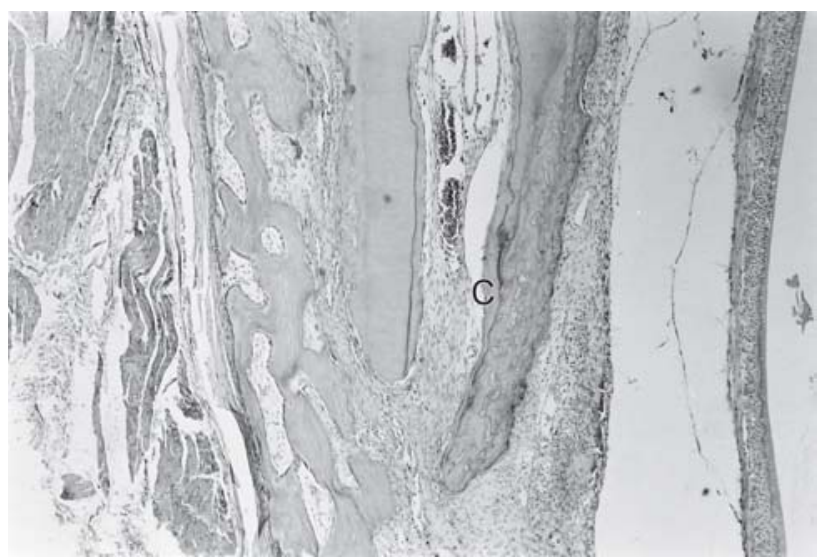

FIGURE 8- Control group. There is newly formed cementum (C) on the walls of the root canal along with ingrowth of periodontal connective tissue. H.E. X 100 
With Maisto paste we observed a chronic inflammatory reaction of variable intensity. The presence of inflammatory reaction was also observed 120 or 180 days after the treatment of dog teeth ${ }^{6}$. Nevertheless, 18 months after root canal filling $35 \%$ of dog teeth showed total apical closure by newly formed cementum and absence of inflammatory reaction ${ }^{7}$.

Sealer 26 is usually not resorbed. For this reason, we added iodoform to the material as did Tagger and Sarnat ${ }^{21}$ (1984) with zinc oxide eugenol cement. Next to Sealer 26 we observed many giant cells and macrophages with particles of the material in their cytoplasm, suggesting resorption. We observed 1 case of complete closure of the apical foramen and 5 cases of partial closure. Some cases of apical closure with this material were also reported after root canal treatment of permanent teeth in dogs ${ }^{19}$.

One of the required properties of a sealer for filling root canals of deciduous teeth is that the material must be resorbed simultaneously with the tooth root. In relation to the resorption of the filling material, the statistical analysis ranked the results from best to worst as follows: L\&C paste, Maisto paste and Sealer 26. A significant difference (5\%) was observed only between Sealer 26 and L\&C paste. This last paste was the most resorbed material, but it was also more irritating than the others. Good biological compatibility is an important property for deciduous root canal filling materials, in order to preserve the integrity of the permanent teeth bud. In our study we did not observe any cases of lesions of the permanent tooth bud, even with the L\&C paste.

\section{CONCLUSIONS}

The Kruskal-Wallis test ranked the groups from the best to the worst in the following way: Maisto paste, Sealer 26, Control group, L\&C paste. Significant difference $(P=0.01)$ was observed only when $L \& C$ paste was compared to the other 3 groups. The L\&C paste showed biological incompatibility and should not be employed as a root canal filling for deciduous teeth. Sealer 26 and Maisto paste were more biocompatible, but their resorption rates were not the same as that of the roots of deciduous teeth.

\section{ACKNOWLEDGEMENT}

To the Foundation for Support to the Research of the State of São Paulo (FAPESP) for funding this study. (Research Project 01/03830-7)

\section{REFERENCES}

1- Alves DF, Caldas Júnior AF, Feitosa DA, Fontes GB, Sant'Anna AO, Rodrigues VMS. Tratamento endodôntico utilizando hidróxido de cálcio em dentes decíduos com polpa necrosada e reação periapical. Rev Fac Odontol Pernambuco. 1994;13(1):45-7.

2- Castagnola L, Orlay HG. A system of endodontic for the general dental practitioner. London, Pitman Medical; 1956.
3- Han GY, Park SH, Yoon TC. Antimicrobial activity of $\mathrm{Ca}(\mathrm{OH})_{2}$ containing pastes with Enterococcus faecalis in vitro. J Endod. 2001;27(5):328-32.

4- Hendry JA, Jeansonne BG, Dummett Júnior CO, Burrell W. Comparison of calcium hydroxide and zinc oxide and eugenol pulpectomies in primary teeth of dogs. Oral Surg Oral Med Oral Pathol. 1982;54(4):445-51.

5- Holan G, Fuks AB. A comparison of pulpectomies using ZOE and KRI paste in primary molars: a retrospective study. Pediatr Dent. 1993;15(6):403-7.

6- Holland R, Maisto OA, Souza V, Maresca BM, Nery MJ. Acción y velocidad de reabsorción de distintos materiales de obturación de conductos radiculares en el tejido conectivo periapical. Rev Asoc Odontol Argent. 1981;69(1):7-17.

7- Holland R, Maisto OA, Souza V, Maresca BM, Nery MJ. Comparación histológica de dientes de perros sobreobturados com tres materiales. Rev Esp Endodoncia. 1986;4(3):79-86.

8- Holland R, Souza V, Nery MJ, Mello W, Bernabé PFE, Otoboni Filho JA. A histological study of the effect of calcium hydroxide in the treatment of pulpless teeth of dogs. J Br Endod Soc. $1979 ; 12(1): 15-23$

9-Holland R, Nery MJ, Mello W, Souza V, Bernabé PFE, Otoboni Filho JA. Root canal treatment with calcium hydroxide. I- Effect of overfilling and refilling. Oral Surg Oral Med Oral Pathol. 1979;47(1):87-92.

10- Holland R, Souza V, Nery MJ, Bernabé PFE, Mello W, Otoboni Filho JA. Comportamento dos tecidos periapicais de dentes de cães com rizogênese incompleta após obturação de canal com diferentes materiais obturadores. Rev Bras Odontol. 1992; 49(3):49-53.

11- Holland R, Souza V, Nery MJ, Bernabé PFE, Otoboni Filho JA, Dezan Junior E Calcium salts deposition in rat connective tissue after the implantation of calcium hydroxide-containing sealers. J Endod. 2002;28(3):173-6.

12- Kubota K, Golden BE, Penugonda B. Root canal filling materials for primary teeth: a review of the literature. ASDC J Dent Child. 1992;59(3):225-7

13- Leonardo MR, Silva LAB, Utrilla LS, Assed S, Ether SS. Calcium hydroxide root canal sealers - histopathologic evaluation of apical and periapical repair after endodontic treatment. J Endod. 1997;23(7):428-32.

14- Lopes H P, Costa Filho AS. Uso do hidróxido de cálcio com veículo oleoso como tampão apical em dentes despolpados com lesões periapicais. R G O. 1988;36(2):133-8.

15- Maisto AO. Endodoncia. 4 ed. Buenos Aires, Mundi; 1984.

16-Maisto OA, Erausquin J. Reacción de los tejidos periapicales del molar de la rata a las pastas de obturación reabsorbibles. Rev Asoc Odontol Argent. 1965;53(1):12-20.

17- Nurko C, Garcia-Godoy F. Evaluation of a calcium hydroxide/ iodoform paste (Vitapex) in root canal therapy for primary teeth. J Clin Pediatr Dent. 1999;23(4):289-94.

18- Péret LRCA. Uso do hidróxido de cálcio no tratamento endodôntico radical de dentes decíduos. Minas Gerais;1999.[Monografia em Odontologia, Endodontia- Faculdade de Odontologia da UFMG]. 
19- Sacomani GRR, Holland R, Souza V, Garlippe O. Comportamento dos tecidos periapicais de dentes de cães após obturação de canal com os cimentos Sealer 26 e Sealer 26 modificado. J B E. 2001;2(5):14552.

20- Silva LAB, Leonardo MR, Utrilla LS. Rizogênese incompleta: efeitos de diferentes pastas à base de hidróxido de cálcio na complementação radicular e na reparação periapical em dentes de cães: estudo histológico. Rev Odontol Univ São Paulo. 1991;5(1): 29-36.

21- Tagger E, Sarnat H. Root canal therapy of infected primary teeth. Acta Odontol Pediat. 1984;5(2):63-6. 